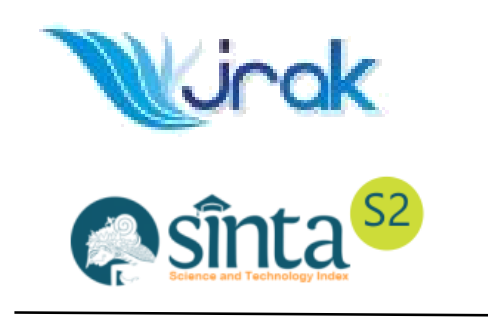

Website:

ejournal.umm.ac.id/index.php/jrak

*Correspondence:

fernando.africano@polsri.ac.id

DOI: $\underline{10.22219 / \text { jrak.v11i1.16256 }}$

Citation:

Akbar, D.A., Africano, F \& Isrodinata, R.. (2021). Can Fraud Diamond Affect Fraud Financial Statement In Sharia Commercial Banks?. Jurnal Reviu Akuntansi dan Keuangan, 11(1), 40-57.

Article Process

Submitted:

April 04, 2021

Reviewed:

April 19, 2021

Revised:

May 3, 2021

Accepted:

May 3, 2021

Published:

May 4, 2021

Office:

Department of Accounting University of

Muhammadiyah Malang

GKB 2 Floor 3.

Jalan Raya Tlogomas 246,

Malang, East Java,

Indonesia

P-ISSN: 2615-2223

E-ISSN: 2088-0685
Article Type: Research Paper

\section{CAN FRAUD DIAMOND AFFECT FRAUD FINANCIAL STATEMENT IN SHARIA COMMERCIAL BANKS?}

\author{
Dinnul Alfian Akbar ${ }^{1}$, Fernando Africano ${ }^{2 *}$, Ridandy \\ Isrodinata ${ }^{1}$, \\ Afiliation: \\ ${ }^{1}$ Islamic Economic and Business Faculty, Universitas Islam Negeri \\ Raden Fatah, Palembang, Indonesia \\ ${ }^{2}$ Business Administration, Politeknik Negeri Sriwijaya, Palembang, \\ Indonesia
}

\section{ABSTRACT}

This research aims to obtain empirical evidence of the effect of fraud diamond (pressure as proxied by financial stability, opportunity which is proxied by effective monitoring, rationalization which is proxied by total accruals, and proxied capability by change of directors) on financial statement fraud at Islamic Commercial Banks. The population in this study were banking companies that were on the list of Islamic Commercial Banks. Then the sample was taken using purposive sampling technique. The research used logistic regression because the dependent variable is a dummy variable. The results of this research indicate that the pressure variable has no effect on financial statement fraud. Opportunity variable has a negative effect on financial statement fraud. Then, the rationalization variable has a negative effect on financial statement fraud. And the capability variable has no effect on financial statement fraud. The results of this study are expected to be useful for companies, especially banking, as a material for consideration in preventing fraud on financial statements.

KEYWORDS: Capability; Financial Statement Fraud; Opportunity; Pressure; Rationalization. 


\section{INTRODUCTION}

Islamic banks as institutions based on Islamic principles are not allowed to manipulate in making financial statements. This is because it can mislead users of financial statements as information on company performance. The National Sharia Council Fatwa No.15 / DSN-MUI / IX / 2000 concerning the Principles of Distribution of Business Results states that for the benefit of financial reports, an accrual basis system should be used. The purpose of Islamic financial management is accountability, both accountability to Allah, the parties who are entitled to the company, and nature. The parties entitled to the company are users of financial statements including the owners of funds, parties who utilize and receive funds distribution, zakat payers, shareholders, supervisory authorities, Bank Indonesia, the government, deposit insurance institutions and the public (Imawan, 2020).

Financial reports are an accountability tool for parties related to the company, such as investors, shareholders, creditors, and others. With this financial report, related parties can make decisions based on considerations of available information. Therefore, the responsible party must provide relevant and transparent information so as not to mislead stakeholders in making decisions ( $R$. A. Putri, 2015).

Developments in the world of accounting that are increasingly advanced have both good and bad impacts on the company's performance, not only bringing benefits to the parties involved but also being the initial source of fraud that occurs in companies, for example, corruption, misuse and manipulation of financial statements. The factors that lead to the formation of fraud in the financial statements make a company that is managed experience a loss that has an impact on the company's performance, on the other hand, the view of fraud forms many theories, one of which is the fraud diamond theory proposed by Wolfe \& Hermanson (2004). Fraud diamond is an adaptation of the fraud triangle theory which adds a qualitative element which is believed to have a significant influence on fraud. The fraud triangle explains 3 elements, namely, Pressure, Opportunity, and Rationalization, while in Diamond Fraud adds 1 element, namely Capability.

The first element of pressure can be concluded as a person's motive for committing fraud based on an urgent need or urge, proxied through financial stability. The second element of opportunity is a situation or opportunity that allows someone to commit an unjustified action such as fraud, this can occur due to weak internal control and uncontrolled supervision, this element is proxied through effective monitoring. The third element of rationalization is concluded where the actor views his illegal action as an act that makes sense, in this element the proxies through total accruals. And the fourth element of capability can be concluded that cheating that occurs a lot will not be realized if without the right people who have the ability to commit fraud, this element is proxied through a change of directors (Wolfe \& Hermanson, 2004 and Mardiyani, 2018).

The existence of the elements above causes the company to become unhealthy because there is no initial signal capture or fraud detection, some companies that experience losses due to fraud are BJB Syariah Bank. BJB Syariah Bank is still involved in a case of alleged fictitious credit which caused the company loss of Rp. 548 billion, according to the 2018 Good Corporate Governance (GCG) report issued by the company, there were 4 cases of internal fraud that

JRAK affected bank operations and financial conditions significantly in 2018 (Arief, 2019). This is based on the opportunity to commit fraud by permanent employees of Bank BJB Syariah, the 11.1 opportunity is in the form of a customer applying for credit but the numbers are manipulated by a responsible employee. 
A company that experienced the same thing was Bank Syariah Mandiri, Bogor Branch, where around 2013 there was a burglary of funds through fictitious financing worth Rp. 102 billion. Bank Syariah Mandiri reported an internal crime to Bareskrim, this crime was committed by three people, namely the Head of the Bogor Main Branch M. Agus, the Head of the Bogor SubBranch Haerul Hermawan, and the Bogor Sub Branch Account Officer John Lopulisa. The suspects are suspected of having committed irregularities in the provision of financing facilities for 197 customers. This includes the part of fraud involving internal companies, where there is a lack of supervision in the company (Tempo.co, 2013).

Fraud cases also occurred at Bank Muamalat Indonesia (BMI) experiencing internal problems and mismanagement. Based on data provided by the Financial Services Authority (OJK), BMI experienced a business contraction after the change of top executives, starting from a drastic decline in profits, a high increase in NPF, and decreased working capital. BMI has been robbed gently by the highest leadership of BMI and a lot of fictitious financing is done intentionally by the management. This is a category where a director fails to carry out the business strategy implemented in the company (TrisnaDewi, 2018).

Apart from banking, fraud can also occur in stock processing companies such as PT. Golden Trades Indonesia Syariah, in this case involved several names of major Indonesian ulama such as Marzukie Ali and KH. Ma'ruf, Amin who at that time served as chairman of the MUI as well as the Supervisory Board of PT. GTIS. In this case, President Director Taufiq Michael Ong took away customer funds amounting to Rp. 10 trillion, PT. GTIS obtained a halal certificate from the MUI and in its marketing PT. GTIS lists the two names of the great scholars Marzuki Alie and KH. Ma'ruf Amin to attract customers to be interested and believe in the money game business that is labeled sharia (Fikri, 2017). Things such as including the part of fraud that involves capability, due to taking advantage of the position of intermediary to commit fraud in order to get their own hands and take advantage of the names of big ulama to attract customers.

The financial statement fraud discussed is a problem that has a very significant impact because of its impact. Therefore, several components of the company must take roles in accordance with their abilities. In addition, so that financial statement fraud does not occur, it must be evaluated and more effective in performance so that financial statement fraud can be detected early before it develops and becomes a case, because gaps in financial statements can become space for individuals to carry out planned fraud. Financial statement fraud was allegedly difficult to detect. This is very common in companies whether in the context of company progress or personal desires.

The results of research conducted by Sihombing \& Rahardjo (2014) prove that there is a significant influence between pressure on financial statement fraud, contrary to Putri's (2015) research which states that there is no influence of pressure on financial statement fraud.

Research conducted by I. G. A. E. P. Putri et al. (2017) shows a significant positive effect between opportunity on financial statement fraud, contrary to research conducted by Fikri (2017) which states that opportunity cannot be used to detect financial statement fraud.

The results of research conducted by Agusputri \& Sofie (2019) show that there is a negative effect of rationalization on financial statement fraud, which is inversely proportional to research conducted by R. A. Putri (2015) which shows that there is no influence of rationalization on financial statement fraud.

The results of research conducted by Wahyuninngtias (2016) show that capability results have an effect on financial statement fraud, in contrast to research conducted by Hanifa \& Laksito (2015) which states that there is no influence between capability on financial statement fraud. 
Based on the results of the existing research, it can be stated that the conflict in determining the results is still not consistent, the detection of fraud is difficult to detect. This indicates a new phenomenon that has developed in several companies and banks. This also encourages researchers to contribute directly to strengthening and safeguarding the early detection of fraud (fraud) in the banking industry in Indonesia. Researchers try to indicate the initial factors representing each of the fraud factors in companies and banks in several periods. This study examines the effect of diamond fraud on financial statement fraud, where this research focuses on indicating fraud in the banking industry for the 2015-2019 period.

This research is expected to contribute to theoretical and practical dimensions. On the conceptual aspect, this research can provide evidence whether or not fraud diamonds affect financial statement fraud at Islamic Banks. Meanwhile, in the practical aspect, this research is expected to be useful for companies, especially banking, as a material consideration to prevent fraud (fraud) on financial statements. This Research therefore goes a long way to guide the regulator and government to formulate and implement policies on shareholding structure in banks. increasing the quality of financial reports will increase confidence in the markets. The most important factor affecting the quality of financial reports is fraud. The loss of fraudulent financial reports to business stakeholders is increasing day by day. In this context, in order to increase the quality of financial reports and eliminate the negative effects of their users, preventive measures must be taken before the emergence of the frauds.

Pressure, according to the Statement on Auditing Standards No. (SAS No.) 9/AU Section 316 incentive, is an inherent factor that motivates individuals to perpetrate fraud. Managers have the motive of incentive-driven fraud because they receive profits based on their firms' target achievability that lead to deceptive financial statements. Besides, managers also have the motive of pressure-driven fraud because they have the opportunity to avoid various situations that potentially harm their firms, such as breaching debt covenant, receiving going concern opinion or reporting loss. Dorminey et al. (2012) suggest that there are four factors that motivate individuals to have fraud intention, namely MICE. Internal pressures emerge because of individuals' economic pressures that lead to fraud intention within these individuals. These life pressures can take the form of family burden or social lifestyles in their working or societal environment. By relying on SAS No.99/AU 316 and the fraud triangle model of Cressey (1953) and also Hogan et al. (2008), Trompeter et al. (2013) consistently categorize three factors that trigger fraud, namely pressure, rationalization and opportunity (fraud triangle). Pressure or commonly labeled as incentive that motivates fraud intention consists of the motive to meet analysts' estimation (Koh et al., 2008), compensation and incentive structure (Armstrong et al., 2013). Pressures can take the form of individuals' condition that encourages unethical actions, namely stress (Piquero et al., 2005), social stress, network and social interaction within the society (Piquero et al., 2005 and Block \& Griffin, 2002). The findings of Bhasin (2016) confirmed that of Said et al. (2017) that pressure is a major determinant of fraud. Contrarily, Sunardi \& Amin (2018) indicates that pressure had negative effect on the occurrence of financial statement fraud among manufacturing companies listed on the Indonesia Stock Exchange. The differences in the findings may be attributed to the focus of Sunardi \& Amin (2018) which was on fraud related to reporting of financial statement and not fraudulent acts among employees of financial institutions. Based on these arguments, this study proposes the following first hypothesis:

JRAK

\section{1}

\section{$\boldsymbol{H}_{1}$ : Pressure affects financial statement fraud}

Opportunity is a condition that is exploited by individuals in organizations when internal control is weak. This study proposes to use the absence of a whistleblowing system as a proxy 
of the opportunity factor because this condition arguably leads to greater opportunities to perpetrate fraud. Whistleblowing is the disclosure by the members of organizations on illegal, immoral actions performed by other members of organizations (Dalton \& Radtke, 2013). Opportunity is the second factor of the fraud triangle that refers to a condition that indicates the weakness of the system within organizations. Trompeter et al. (2013) explain opportunity within the Committee of Sponsoring Organizations of the Treadway Commission framework (COSO, 2013) that consists of five components: the control environment, risk management, control activities, information and communication and monitoring. Opportunity mostly falls under the control environment, including audit committees (Archambeault et al., 2008 and Magilke et al., 2009), the board of director (Collins et al., 2009) and the weakness of internal control (Smith et al., 2000). Further, Dellaportas (2013) empirically shows the relationship between opportunity and fraud in the case of asset misappropriation. Specifically, the weak internal control system provides opportunities for perpetrators to exploit their abilities to manipulate the existing system undetected. Said et al. (2018) support these findings by demonstrating the relationship between opportunity and fraud in the form of asset misappropriation. Different studies have been carried on fraud in organizations and the general view is that opportunity positively relates to occurrence of fraud (Schuchter \& Levi, 2016, Abdullahi \& Mansor, 2018, and Asmah et al., 2020). Said et al. (2017) integrated ethics into the fraud triangle theory in detecting fraud in the banking system of Malaysia. They found Opportunity related positively to employee fraud. Likewise, Bonsu et al. (2018) found weaker internal control, inadequate training and fraud policies as the major causes of fraud in the financial institutions in Ghana. Other studies affirm the assertion that internal control weaknesses can be major contributing factors for fraud to be committed (Akomea-Frimpong et al., 2016 and Asmah et al., 2020). According to Asmah et al. (2020), inadequate controls in some areas of banks can fuel the commission of fraud among bank employees. Moreover, poor supervision and improper documentation process provide opportunity to misappropriate the assets, especially when it includes several people that cooperate to conduct those illegal malpractices (Zakaria et al., 2016). Similarly, limited separation of duties, false documentation and inadequate or non-existence of control system accounted for fraud in the Indian banking system (Bhasin, 2016). Based on these arguments, this study proposes the following second hypothesis:

\section{$\boldsymbol{H}_{2}$ : Oppurtunity Affects Fraud Financial Statement}

Trompeter et al. (2013) empirically indicate that non-accounting scholars have extensively investigated rationalization in various settings. In general, the rationalization factor in the fraud triangle arguably precedes a fraudulent act. Individuals with fraud intention tend to experience conflicts within themselves or cognitive dissonance. (Ashforth \& Anand, 2003) propose eight types of denials to rationalize fraud (corruption), namely the denial of legality, denial of responsibility, denial of injury, denial of victim, social weighting, appeal to higher loyalties, the metaphor of the ledger and refocusing attention. Rationalization facilitates individuals to mitigate their cognitive dissonance (Ramamoorti, 2008). Rationalization is decision-makers' ability to perpetrate fraud and to justify that their actions are reasonable. Trompeter et al. (2013) empirically demonstrate that rationalization (moral justification after the fraud) is closely related to the neutralization construct (moral justification before the fraud). The fraud rationalization emerges because of the justification that corporate crimes committed give advantages to organizations (Piquero et al., 2005). The cognitive dissonance theory explains the condition when individuals rationalize their behavior by the concepts that they create themselves (Festinger, 1957). Cognitive dissonance is individuals' internal conflicts when they conduct unethical actions that are inconsistent with their beliefs. Rationalization as justification of fraud

\section{JRAK} 11.1 
by the fraudsters with their own opinionated feelings or beliefs (Akomea-Frimpong et al., 2016)

is found to be positively related to fraud among employees. Sunardi \& Amin (2018) indicates that rationalization relates positively to employee fraud. Poor remuneration which may form the bases for justifying the criminal conduct has been found as a major cause of fraud among employees of financial institutions of Ghana (Bonsu et al., 2018) and in the insurance industry of Ghana (Akomea-Frimpong et al., 2016). Reurink, (2018) also identifies perverse incentive structures in the financial industry which is a condition for rationalization elements of the fraud theories of Cressey (1953) and Wolfe \& Hermanson, (2004). Lack of understanding of fraud behaviour can also lead people to commit fraud and can be likened to the elements of rationalization in the fraud triangle theory (Omar et al., 2016). Based on these arguments, this study proposes the following third hypothesis:

\section{$\boldsymbol{H}_{3:}$ Rationalization Affects Fraud Financial Statement}

Wolfe \& Hermanson (2004) argue that capability triggers fraud. Capability is individuals' ability to control their organizations. The ACFE Report 2018 documents that highly capable individuals (top management) perpetrate more frauds than those in the low-management position. Fraudsters arguably exist in every organizational line. However, those with high capability have more power to control their frauds. Fraudsters are typically first-time offenders, middle-aged, well-educated, trusted employees and/or considered good citizens in their occupations (Ramamoorti, 2009). Fraud committed by top management is widely known as white-collar crime. Wolfe \& Hermanson (2004) develop the fraud triangle into the fraud diamond by adding the fourth factor (capability). Further, Dorminey et al. (2012) explain that capability modifies the opportunity construct by limiting opportunity in the sense that individuals have to have appropriate skills to use the opportunity. This argument is in line with the fact that individuals with high capability (as top managers) tend to perpetrate more fraud than low managers (ACFE, 2018). Positive relationship has been found between capability and bank-related fraud in the Saudi Arabian banking sector (Baz et al., 2016). Sunardi \& Amin (2018) also confirmed that capability had positive effect on the occurrence of financial statement fraud among manufacturing companies listed on the Indonesia Stock Exchange. Likewise, Reurink (2018) also confirmed that capability elements such as influx of unsophisticated technology and gullible participants in the financial market place serve as weapons that equip the criminals to execute the malicious deals. It has also been found that capability influences academic fraudulent behaviour of students (Muhsin et al., 2018). Based on these arguments, this study proposes the following fourth hypothesis:

\section{$\boldsymbol{H}_{4}$ : Capability Affects Fraud Financial Statement}

\section{METHOD}

This study uses population of 14 Islamic Commercial Bank that carried out in the 2015-2019 period. However, of the 14 Islamic Commercial Banks, only twelve banks (Bank Muamalat Indonesia, Bank Syariah Mandiri, Bank Mega Syariah, Bank BRI Syariah, Bank BNI Syariah, Bank Syariah Bukopin, Bank Jabar Banten Syariah, Bank BCA Syariah, Bank Victoria Syariah, Panin Dubai Syariah Bank, Bank BTPN Syariah and Bank Aceh Syariah) were sampled because the data were available during the study period.

JRAK Financial statement fraud is an act either done intentionally or negligently that results in material errors in the financial statements and provides incorrect information to users of 11.1 financial statements or stakeholders (Parlindungan et al., 2017). This research uses the Beneish M-Score formula. If the Beneish M-Score is more than -2.22 , it can be categorized that the banking company has committed a fraud. Conversely, if the value is less than -2.22 , the 
company has not committed fraud. Then for banking companies that have committed fraud is categorized as "1", and for banking companies that have not committed fraud are given a score of "0" (Caesar, 2017). Beneish M-Score model is a probabilistic model, so it will not detect fraud with 100\% accuracy. Beneish M-Scoremodel has 8 variables (Beneish et al., 2012), as follows:

1. Days Sales in Receivables Index (DSRI):

2. Gross Margin Index (GMI)

3. Asset Quality Index (AQI)

4. Sales Growth Index (SGI)

5. Depreciation Index (DEPI)

6. Sales General and Administrative Expenses Index (SGAI)

7. Leverage Index (LVGI)

8. Total Accruals to Total Assets (TATA)

The Beneish M-Score Model formula is as follows (Beneish et al., 2012):

M-Score $=-4.84+0.920$ DSRI $+0.528 \mathrm{GMI}+0.404 \mathrm{AQI}+0.892 \mathrm{SGI}+0.115 \mathrm{DEPI}-$ 0.172 SGAI - 0.327 LVGI + 4.697 TATA

Pressure can be concluded as a person's motive for committing fraud based on an urge or urgent need (Wolfe \& Hermanson, 2004), proxied through financial stability. Financial stability is a condition that describes the financial stability of a banking company or can be said to be in good condition, to see the stability of a banking company in terms of how the state of its assets is. Total assets represent all assets owned by a banking company, whether current assets or non-current assets. The calculation of financial stability uses the percentage change in total assets method where the ratio of changes in assets for two periods. Pressure is calculated using the formula (Omukaga, 2020):

$$
\text { Pressure }=\frac{\text { Total Asset }(t)-\text { Total Asset }(t-1)}{\text { Total Asset }(t)}
$$

Opportunity is a situation or opportunity that allows someone to commit unjustified actions such as fraud, this can occur because of weak uncontrolled internal control and control (Wolfe \& Hermanson, 2004), this element is proxied through ineffective monitoring. Ineffective monitoring is where a company does not have a supervisory unit that does not work effectively in company management. This study uses the ratio of the number of independent commissioners to the total existing board of commissioners. Opportunity is calculated using the formula (Noble, 2019):

$$
\text { Opportunity }=\frac{\text { Number of Independent Commisioners }}{\text { Total number of Commisioners }}
$$

Rationalization is where looking for rational reasons in committing fraud, a person's character causes one or more individuals to commit fraud (Wolfe \& Hermanson, 2004). In this study, the element of rationalization is measured using total accruals. Opportunity is calculated using the formula (Skousen et al., 2011):

\section{Ratioalization}

$$
\begin{aligned}
& =\text { Net Income } \\
& - \text { Cash Flow from Operating Activitie }
\end{aligned}
$$


The capability of a person in a banking company greatly influences the possibility of a person committing fraud (Wolfe \& Hermanson, 2004). Changes in the board of directors will result in period stress which will increase the chances of fraud occurring. Therefore in this study proxies capability with a change of directors as measured by a dummy variable where if there is a change of directors in the company during the 2015-2019 period it is given code 1 , and if there is no change of directors during the 2015-2019 period it will be coded 0 (Noble, 2019).

Data analysis using logistic regression analysis. Furthermore, the multicollinearity test was carried out in the model (Africano, 2020). The regression model will be tested for its feasibility, whether it is able to predict financial statement fraud or not, seen through the Hosmer and Lemeshow's Goodness of Fit Test whether the data is in accordance with the observed data. Overall model fit test is a test or assessing the entire model against the data, testing aims to see whether the logistic regression model used is fit or not. Cox and Snell R Square is a measure that tries to mimic the $\mathrm{R}$ measure on multiple regression and is based on the likelihood estimation technique with a maximum value of less than 1 so it is difficult to interpret. Therefore, to get a coefficient of determination that can be interpreted like R2 in multiple regression, we use Nagelkereke R Square where the value varies between 0-1. Nagelkereke R Square is a modification between the Cox and Snell coefficients (Ghozali \& Ratmono, 2013). Hypothesis testing with logistic regression models uses the Wald test and p-value (probability value).

\section{RESULTS AND DISCUSSION}

Multicollinearity Analysis

\begin{tabular}{|c|c|c|c|c|c|}
\hline & Pressure & Oppurtunity & Rationalization & Capability & \\
\hline Pressure & 1.000000 & 0.042089 & -0.148741 & -0.011209 & \\
\hline Oppurtunity & 0.042089 & 1.000000 & -0.087450 & 0.062321 & Multicollinearity \\
\hline Rationalization & -0.148741 & -0.087450 & 1.000000 & -0.176880 & Analysis Results \\
\hline Capability & -0.011209 & 0.062321 & -0.176880 & 1.000000 & \\
\hline
\end{tabular}

Based on table 1, it shows that the value of all independent variables (pressure, opportunity, rationalization and capability) is less than 0.09 , which means that there is no correlation between variables (Ghozali, 2016). This shows that there are no symptoms of multicollinearity.

\section{Goodness of Fit Test}

Hosmer and Lemeshow's is a tool to test the null hypothesis that there is no difference between the model and the data so that the model can be said to be fit. If the HL Goodness of fit statistical value is greater than 0.05 , it means that the model is able to predict the value of the observation or it can be said that the model is acceptable because it fits the research data (Ghozali \& Ratmono, 2013). The following is an assessment of the Hosmer and Lemeshow's test value which is presented in table 2 below :

\begin{tabular}{lccc}
\hline H-L Statistic & 14.5613 & Prob. Chi-Sq(8) & 0.0683 \\
\hline Andrews Statistic & 24.4158 & Prob. Chi-Sq(10) & 0.0066 \\
\hline
\end{tabular}

Table 2.

Goodness of Fit Test Results 
It can be seen from table 2 that the statistical HL value is 14.5613 with a significant probability of 0.0683 which is above 0.05 . This shows that the model is acceptable or fit.

\section{Assessing the Eligibility of the Overall Model Fit Test (Overall Model Fit Test)}

This test uses the likelihood ratio (LR) statistical test, which aims to determine the effect of independent variables on dependent variables in the regression model (Ghozali \& Ratmono, 2013).

Table 3.

\begin{tabular}{lcll}
\hline McFadden R-squared & 0.243172 & Mean dependent var & 0.633333 \\
S.D. dependent var & 0.485961 & S.E. of regression & 0.419530 \\
Akaike info criterion & 1.161377 & Sum squared resid & 9.680311 \\
Schwarz criterion & 1.335906 & Log likelihood & -29.84131 \\
Hannan-Quinn criter. & 1.229645 & Deviance & 59.68263 \\
Restr. deviance & 78.85893 & Restr. log likelihood & -39.42947 \\
LR statistic & 19.17630 & Avg. log likelihood & -0.497355 \\
Prob(LR statistic) & 0.000726 & & \\
\hline
\end{tabular}

Based on the results of the analysis, the prob value (LR statistic) is 0.000726 , where this result is less than 0.05 , it can be concluded that the independent variables jointly affect the dependent variable.

\section{Determination Coefficient Test (R2 McFadden)}

The McFadden R2 coefficient of determination is used to measure how much the ability of the dependent variable or independent variable to explain the dependent variable (Ghozali \& Ratmono, 2013), which is mentioned in table 4 below:

\begin{tabular}{lcll}
\hline McFadden R-squared & 0.243172 & Mean dependent var & 0.633333 \\
S.D. dependent var & 0.485961 & S.E. of regression & 0.419530 \\
Akaike info criterion & 1.161377 & Sum squared resid & 9.680311 \\
Schwarz criterion & 1.335906 & Log likelihood & -29.84131 \\
Hannan-Quinn criter. & 1.229645 & Deviance & 59.68263 \\
Restr. deviance & 78.85893 & Restr. log likelihood & -39.42947 \\
LR statistic & 19.17630 & Avg. log likelihood & -0.497355 \\
Prob(LR statistic) & 0.000726 & & \\
\hline
\end{tabular}

Detemination Coefficient Test Results (R2

Likelihood io Test 
Based on the above results, it is stated that the McFadden R-Squared is 0.243172 where this result explains the variability of the dependent variable which can be explained by the variability of the independent variable by $24.32 \%$ and the remaining $75.68 \%$ is explained by other variables outside the model. Logistic Regression Analysis

Table 5 Logistic Regression Test Results

\begin{tabular}{|c|c|c|c|c|}
\hline Variable & Coefficient & Std. Error & z-Statistic & Prob. \\
\hline $\mathrm{C}$ & 3.857253 & 1.597478 & 2.414589 & 0.0158 \\
\hline Pressure & 1.648844 & 1.653597 & 0.997126 & 0.3187 \\
\hline Oppurtunity & -7.294020 & 2.763498 & -2.639416 & 0.0083 \\
\hline Rationalization & $-7.07 \mathrm{E}-10$ & $3.15 \mathrm{E}-10$ & -2.245733 & 0.0247 \\
\hline Capability & 0.586378 & 0.636153 & 0.921755 & 0.3567 \\
\hline $\begin{array}{l}\text { McFadden } \\
\text { squared }\end{array}$ & 0.243172 & $\begin{array}{l}\text { Mean dependent } \\
\text { var }\end{array}$ & 0.633333 & \\
\hline S.D. dependent var & 0.485961 & S.E. of regression & 0.419530 & \\
\hline Akaike info criterion & 1.161377 & Sum squared resid & 9.680311 & \\
\hline Schwarz criterion & 1.335906 & Log likelihood & -29.84131 & \\
\hline $\begin{array}{l}\text { Hannan-Quinn } \\
\text { criter. }\end{array}$ & 1.229645 & Deviance & 59.68263 & \\
\hline Restr. deviance & 78.85893 & $\begin{array}{l}\text { Restr. } \\
\text { likelihood }\end{array}$ & -39.42947 & \\
\hline LR statistic & 19.17630 & Avg. log likelihood & -0.497355 & \\
\hline Prob(LR statistic) & 0.000726 & & & \\
\hline Obs with Dep $=0$ & 22 & Total obs & 60 & \\
\hline Obs with Dep=1 & 38 & & & \\
\hline
\end{tabular}

Table 5.

Logistic Regression Test Results

Based on table 5 above, it can be concluded that:

\section{Effect of Pressure on Fraud Financial Statement}

The coefficient of the pressure variable is 1.648844 and the significance value is 0.3187 , where stability is 0.3187 greater than the 0.05 significance level. So it can be concluded that there is no

11.1 influence on financial statement fraud.

This can occur because the pressure proxied by the financial stability of the company or the bank as a whole does not affect shareholders or investors to maintain their invested funds in 
the company, shareholders do not emphasize the company to remain stable even when the company loses money. At the same time, pressure from internal and external offices does not necessarily affect the company's financial stability. Therefore, the possibility of financial statement fraud is also getting smaller.

Pressure is a condition in which the management as an agent is required to work hard as much as possible to provide the best results for shareholders in the form of increasing profits every year. This condition can be classified as the pressure experienced, where the company must continue to provide good service even though conditions are experiencing a decline. This has prompted several companies to manipulate or replace some data so that the financial statements are considered by shareholders or investors, this decision is taken solely so that the company is considered capable of being accountable for its performance during the period concerned.

The results of this research support the results of research conducted by Farida's (2017) and Ratmono et al. (2018). Yesiariani \& Rahayu (2016) said that the company may have a very good level of supervision carried out by the Board of Commissioners to monitor and control the actions of management that are directly responsible for business functions such as finance, so even though management faces pressure when financial stability is threatened by economic, industrial and economic conditions. the situation of the operating entity will not affect the fraudulent financial statements.

In contrast to the results of research conducted by Tiffani \& Marfuah (2017), Skousen et al. (2011), and Caesar's (2017). One of the forms of manipulation in financial reports by management is related to the growth of company assets Skousen et al. (2011). The high assets owned by the company attracts investors. In order to attract investors, the company's management certainly tries its best to present a company image through convincing financial reports for investors, one of which is the high assets owned.

\section{Effect of Oppurtunity on Fraud Financial Statement}

The oppurtunity variable has a coefficient value of -7.294020 and a significant value of 0.0083 which is greater than the significance level of 0.05 . This shows that opportunity has an effect on financial statement fraud. This can occur due to the weakness and ineffectiveness of supervision in a company or a bank, so the potential for financial statement fraud to occur. With the ineffectiveness of supervision, the management of a company or bank will feel unsupervised, thus creating opportunities for someone to seek opportunities for themselves. This variable uses the ratio of the independent board of commissioners, where the independent board of commissioners has the duty to maintain, supervise and guarantee the accountability of a company or bank that is unable to carry out its duties properly. Ineffectiveness in supervision has led to manipulation of financial data resulting in financial statement fraud.

Opportunity is a lack of supervision or ineffectiveness in supervising a company or a bank, resulting in financial statement fraud, with weak supervision of a company or bank, it will make management feel that they are not being closely monitored so that they will find it easy to find ways to commit fraud in order to provide personal benefits.

The results of this study are in line with the research conducted (I. G. A. E. P. Putri et al., 2017) which states that there is an effect between opportunity and financial statement fraud. Faidah \& Suwarti (2018), where they said that the opportunity proxied by the Board of Commissioners is very effective in maintaining, supervising and controlling a company or banking.

JRAK

11.1 
In contrast to results of research conducted by Sihombing \& Rahardjo (2014), (Martantya \& Daljono, 2013) who stated ineffective monitoring had no significant effect on financial statement fraud. More and more independent commissioners are expected to be able to improve company performance, but it will be different if there are interventions that result in the objectivity of supervision (Nurbaiti \& Hanafi, 2017). The number of independent directors has no effect on fraud on the financial statements because the number of the board of commissioners has been regulated in the Decree of the Chairman of Bapepam LK Number: Kep-643 / BL / 2012 concerning the Establishment and Guidelines for the Audit Committee's Work Implementation.

\section{The Effect of Rationalization on Financial Statement Fraud}

The rationalization variable coefficient has a value of -7.07 and a significant value of 0.0247 where this result is less than the significance level of 0.05 . This shows that rationalization affects financial statement fraud.

Rationalization, which is proxied by total accruals, is a reflection of the financial activities of a company or bank, the value of current assets, current liabilities, operating cash flows that can describe financial statement fraud. The management of a company or bank has rational reasons for committing fraud in accounting so that it assumes that it does not have an immaterial impact, one example is utilizing what is contained in financial statements such as manipulating income by recording when transactions occur even though cash has not yet been received. Total accruals are a reflection of the company's overall activities. The company's accrual rate will vary depending on management decisions regarding certain policies. The results of this research indicate that the accrual principle is related to management decision making and provides insight into.

The results of the study support Iqbal \& Murtanto (2016) where he states that rationalization which is proxied by total accruals has an important role in the occurrence of fraud, attitudes or characters are the cause of an individual or more in rationalizing committing fraud. The higher the total accrual value, the higher the incidence of fraud occurring at the company or bank. In contrast to research conducted by R. A. Putri (2015), it is difficult to use rationalization as a benchmark for someone to commit fraud, a person's motive for manipulating corporate or banking financial data is very low.

In contrast to the results of Ardiyani \& Utaminingsih (2015) and Skousen et al. (2011) which show that TATA has no significant effect on fraudulent financial statements. Ardiyani \& Utaminingsih (2015) state that the use of management policies is not high for or motives to manipulate earnings is low. Skousen et al. (2011) states that rationalization is the most difficult element to indicate measurement, because rationalization is an attitude of justification made by management, employees, or the board of commissioners.

\section{Effect of Capability on Fraud Financial Statement}

The capability variable has a coefficient value of 0.586378 and a significant value of 0.3567 where the value is greater than the significance level of 0.05 . This explains that the capability variable which is proxied by a change of directors has no effect on financial statement fraud. This happens because in the position of the position there is an improvement in the company's

JRAK performance by recruiting directors who have a good work track record and are more competent than the previous directors.

Fraud will not occur if there is no right person and have the right abilities, a person who commits fraud must have the capability to realize the opportunities that are open to commit fraud and use it not only once but on a multiple scale. A person's capability level is very 
influential on the fraud he does, the higher a person's capability in holding a position in an agency / company, the greater the nominal loss incurred. However, the results of this study indicate that the capability that is proxied by a change of directors is not able to be an indicator of fraud, because changes in directors can occur because of two things, namely finding directors who are more competent or covering up mistakes or frauds committed by previous directors.

The results of this study are in line with Yesiariani \& Rahayu (2016) and Noble's (2019) research, which states that capability has an influence on financial statement fraud. This research does not support Suryani's (2019) research, where she states that capability, which is proxied by a change of directors, is the background for the occurrence of financial statement fraud. This happens because the board of directors previously knew the weak points of a company so that it was easy to commit financial statement fraud. In line with research conducted by Hanifa \& Laksito (2015), it is said that the change of directors is one way for companies to find directors who are more competent than previous directors, the change of directors cannot be related to the fact that the previous directors were involved in fraud.

In contrast to the results of Wolfe \& Hermanson (2004) which showed capability had a significant effect on fraudulent financial statements. Wolfe \& Hermanson (2004) say that a change in the board of directors can indicate fraud. Changes in the board of directors are the company's efforts to get rid of directors who are considered to be aware of fraud committed by the company and changes in directors are deemed to require adaptation time so that initial performance is not optimal.

\section{CONCLUSION}

Based on the results of tests conducted by this research, Pressure which is proxied by financial stability has no effect on financial statement fraud, Oppurtunity which is proxied by effective monitoring has an effect on financial statement fraud, Rationalization which is proxied by total accruals has an effect on financial statement fraud and Capability which is proxied by changes Directors have no effect on financial statement fraud. This research has been limited by the sample size and focuses on Islamic Commercial Banks and where the number of companies is still small. Research still has results that contradict the results of previous studies. The testing period in this study was 5 years so it was unable to provide an accurate picture. Future research is expected to use other research variables related to financial factors, non-financial factors, and economic conditions in order to obtain different results so that they can be used as guidelines for further research. The research will contribute to the body of existing knowledge through the following ways: The research contributes to the existing knowledge by expressing the views of different academic scholars with the regards to fraud diamond theory as such the research may serve as a source of academic literature. The research will help the forensic accountants, auditors, fraud examiners and other anti-fraud bodies to understand fraud diamond theory, which will assist them in identifying and investigating the remote cause of fraud concealment and effective assessment of fraud risk. The study may serve as guidance for further research to be carried out on the subject matter in areas that the study did not address.

\section{REFERENCES}

Abdullahi, R., \& Mansor, N. (2018). Fraud Prevention Initiatives in The Nigerian Public Sector: Understanding The Relationship of Fraud Incidences and The Elements of Fraud Triangle Theory. Journal of Financial Crime, 25(2), 527-544. 
Africano, F. (2020). Ekonometrika: Teori dan Aplikasi dengan SPSS. Rafah Press.

Agusputri, H., \& Sofie. (2019). Faktor - Faktor Yang Berpengaruh Terhadap Fraudulent Financial Reporting Dengan Menggunakan Analisis Fraud Pentagon. Jurnal Informasi, Perpajakan, Akuntansi, Dan Keuangan Publik, 14(2), 105. https://doi.org/10.25105/jipak.v14i2.5049

Akomea-Frimpong, I., Andoh, C., \& Eric, D. O.-H. (2016). Causes, Effects and Deterrence of insurance Fraud: Evidence from Ghana. Journal of Financial Crime, 23(4), 1-26. http://dx.doi.org/10.1108/eb025814\%5Cnhttp://

Archambeault, D. S., Dezoort, F. T., \& Hermanson, D. R. (2008). Audit Committee Incentive Compensation and Accounting Restatements. Contemporary Accounting Research, 25(4), 965-992. https://doi.org/10.1506/car.25.4.1

Ardiyani, S., \& Utaminingsih, N. S. (2015). Analisis Determinan Financial Statement Melalui Pendekatan Fraud Triangle. Accounting Analysis Journal, 4(1), 1-10. https://doi.org/10.15294/aaj.v4i1.7761

Arief, T. (2019). Terjadi 4 Internal Fraud di BJB Syariah Selama 2018. Finansial Bisnis.

Armstrong, C. S., Larcker, D. F., Ormazabal, G., \& Taylor, D. J. (2013). The Relation Between Equity Incentives and Misreporting: The Role of Risk-Taking Incentives. Journal of Financial Economics, 109(2), 327-350. https://doi.org/10.1016/j.jfineco.2013.02.019

Ashforth, B. E., \& Anand, V. (2003). The Normalization of Corruption in Organizations. Research in Organizational Behavior, 25(03), 1-52. https://doi.org/10.1016/S01913085(03)25001-2

Asmah, A. E., Atuilik, W. A., \& Ofori, D. (2020). Antecedents and Consequences of Staff Related Fraud in The Ghanaian Banking Industry. Journal of Financial Crime, 27(1), 188-201. https://doi.org/10.1108/JFC-03-2019-0034

Baz, R., Samsudin, R. S., Che-Ahmad, A. B., \& Popoola, O. M. J. (2016). Capability Component of Fraud and Fraud Prevention in The Saudi Arabian Banking Sector. International Journal of Economics and Financial Issues, 6(4), 68-71.

Beneish, M. D., Lee, C. M. C., \& Nichols, D. C. (2012). Fraud Detection and Expected Returns. SSRN Electronic Journal. https:// doi.org/10.2139/ssrn.1998387

Bhasin, M. L. (2016). Combatting Bank Frauds by Integration of Technology : Experience of a Developing Country. British Jouranl of Research, 3(3), 1-29.

Block, A. A., \& Griffin, S. P. (2002). Transnational Financial Crime: Crooked Lawyers, Tax Evasion, and Securities Fraud. Journal of Contemporary Criminal Justice, 18(4), 381-393. https://doi.org/10.1177/104398602237684

Bonsu, O.-A. M., Dui, L. K., Muyun, Z., Asare, E. K., \& Amankwaa, I. A. (2018). Corporate Fraud: Causes, Effects, and Deterrence on Financial Institutions in Ghana. European Scientific Journal, 14(28), 315-335. https://doi.org/10.19044/esj.2018.v14n28p315

11.1 Caesar, M. (2017). Analisis fraud Diamond dalam Mendeteksi Financial Statement Fraud (Studi pada Perusahaan Property, Real Estate and Building Construction yang Terdaftar di Bursa Efek Indonesia Tahun 2011-2015). In Uversitas Islam Negeri Syarif Hidayatullah, Jakarta. 
Collins, D. W., Gong, G., \& Li, H. (2009). Corporate Governance and Backdating of Executive Stock Options. Contemporary Accounting Research, 26(2), 403-445. https://doi.org/10.1506/car.26.2.4

COSO, C. of S. O. of the T. C. (2013). Internal Control - Integrated Framework: Guidance on Monitoring Internal Control Systems,. COSO.

Cressey, D. R. (1953). Other People's Money; a Study in the Social Psychology of Embezzlement. Free Press.

Dalton, D., \& Radtke, R. R. (2013). The Joint Effects of Machiavellianism and Ethical Environment on Whistle-Blowing. Journal of Business Ethics, 117(1), 153-172. https://doi.org/10.1007/s10551-012-1517-x

Dellaportas, S. (2013). Conversations with Inmate Accountants: Motivation, Opportunity and The Fraud Triangle. Accounting Forum, 37(1), 29-39. https://doi.org/10.1016/j.accfor.2012.09.003

Dorminey, J., Scott Fleming, A., Kranacher, M. J., \& Riley, R. A. (2012). The Evolution of Fraud Theory. Issues in Accounting Education, 27(2), 555-579. https://doi.org/10.2308/iace-50131

Faidah, F., \& Suwarti, T. (2018). Deteksi Financial Statement Fraud dengan Analisis Fraud Pentagon pada Perusahaan Manufaktur yang Terdaftar di Bursa Efek Indonesia Periode Tahun 2015-2017. Dinamika Akuntansi Keuangan Dan Perbankan, 7(2).

Farida, S. N. (2017). Analisis pengaruh fraud diamond, personal attitude dan effectiveness of internal control terhadap tendensi kecurangan karyawan pada dealer otomotif di wilayah .... In Jurusan Akuntansi. Fakultas Ekonomi. Universitas Islam Negeri Maulana Malik Ibrahim Malang. http://etheses.uin-malang.ac.id/id/eprint/9600

Festinger, L. (1957). A Theory of Cognitive Dissonance. Stanford University Press.

Fikri, M. K. (2017). Mengkaji Pendeteksian Financial Statement Fraud melalui Pendekatan Faktor Pressure, Opportunity, Rationalization, dan Capability dalam Perspektif Analisis Fraud Diamond. In Skripsi. Ekonomi Islam. Fakultas Ekonomi dan Bisnis Islam. Universitas Islam Negeri Walisongo.

Ghozali, I. (2016). Aplikasi Analisis Multivariete dengan Program IBM SPSS 23.

Ghozali, I., \& Ratmono, D. (2013). Analisis multivariat dan ekonometrika: Teori, konsep, dan aplikasi dengan EVIEWS 8. Badan Penerbit Universitas Diponegoro.

Hanifa, S. I., \& Laksito, H. (2015). Pengaruh Fraud Indicators Terhadap Fraudulent Financial Statement: Studi Empiris Pada Perusahaan Yang Listed Di Bursa Efek Indonesia (Bei) Tahun 2008-2013. Diponegoro Journal of Accounting, 4(4), 1-15.

Hogan, C. E., Rezaee, Z., Riley, R. A., \& Velury, U. K. (2008). Financial Statement Fraud: Insights from the Academic Literature. Auditing: A Journal of Practice \& Theory, 27(2), 231-252. https:// doi.org/10.2308/aud.2008.27.2.231

Imawan, A. (2020). Analisis Pengaruh Fraud Pentagon dalam Terhadap Fraudulent Financial Reporting dengan Komite Audit Sebagai Variabel Moderasi Pada Bank Umum Syariah di .... In Skripsi. Salatiga: Fakultas Ekonomi dan Bisnis Islam IAIN Salatiga. http://e-repository.perpus.iainsalatiga.ac.id/id/eprint/8743

JRAK

11.1

Iqbal, M., \& Murtanto. (2016). Analisa Pengaruh Faktor-faktor Fraud Triangle terhadap Kecurangan Laporan Keuangan pada Perusahaan Property dan Real Estate yang 
Terdaftar di Bursa Efek Indonesia. Seminar Nasional Cendekiawan 2016, ISSN: 2540 7589, 17.1-17.20.

Koh, K., Matsumoto, D. A., \& Rajgopal, S. (2008). Meeting or Beating Analyst Expectations in the Post-Scandals World: Changes in Stock Market Rewards and Managerial Actions. Contemporary Accounting Research, 25(4), 1067-1098. https://doi.org/10.1506/car.25.4.5

Magilke, M. J., Mayhew, B. W., \& Pike, J. E. (2009). Are Independent Audit Committee Members Objective? Experimental Evidence. The Accounting Review, 84(6), 1959-1981. https://doi.org/10.2308/accr.2009.84.6.1959

Mardiyani, I. (2018). Pengaruh Fraud Diamond terhadap Kecurangan dalam Laporan Kenangan (Studi pada Perusahaan Sektor Pertambangan di Bursa Efek Indonesia 2012-2016).

Martantya, \& Daljono. (2013). Pendeteksian Kecurangan Laporan Keuangan Melalui Faktor Risiko, Tekanan dan Peluang (Studi Kasus pada Perusahaan yang Mendapat Sanksi dari Bapepam Periode 2002-2006). Diponegoro Journal of Accounting, 2(2), 1-12.

Muhsin, Kardoyo, \& Nurkhin, A. (2018). What Determinants of Academic Fraud Behavior? From Fraud Triangle to Fraud Pentagon Perspective. KnE Social Sciences, 3(10), 154-167. https://doi.org/10.18502/kss.v3i10.3126

Noble, M. R. (2019). Fraud diamond analysis in detecting financial statement fraud. The Indonesian Accounting Review, 9(2), 121. https://doi.org/10.14414/tiar.v9i2.1632

Nurbaiti, Z., \& Hanafi, R. (2017). Analisis Pengaruh Fraud Diamond Dalam Mendeteksi Tingkat Accounting Irregularities. Jurnal Akuntansi Indonesia, 6(2), 167. https://doi.org/10.30659/jai.6.2.167-184

Omar, M., Nawawi, A., \& Salin, A. S. A. P. (2016). The Causes, Impact and Prevention of Employee Fraud. Journal of Financial Crime, 23(4), 1012-1027. https://doi.org/10.1108/jfc-04-2015-0020

Omukaga, K. O. (2020). Is the Fraud Diamond Perspective Valid in Kenya? Journal of Financial Crime. https://doi.org/10.1108/JFC-11-2019-0141

Parlindungan, R., Africano, F., \& Elizabeth, P. S. M. (2017). Financial Statement Fraud Detection Using Published Data Based on Fraud Triangle Theory. Advanced Science Letters, 23(8), 7054-7058(5).

Piquero, N. L., Tibbetts, S. G., \& Blankenship, M. B. (2005). Examining the Role of Differential Association and Techniques of Neutralization in Explaining Corporate Crime. Deviant Behavior, 26(2), 159-188. https://doi.org/10.1080/01639620590881930

Putri, I. G. A. E. P., Sulindawati, N. L. G. E., \& Atmadja, A. T. (2017). Pengaruh Financial Targets Dan Ineffective Monitoring Terhadap Terjadinya Fraud (Studi Kasus Pada Koperasi Serba Usaha Dana Pertiwi Seririt, Kecamatan Seririt, Kabupaten Buleleng, Provinsi Bali). JIMAT (Jurnal Ilmiah Mahasiswa Akuntansi) Undiksha, 7(1), 1-11. https://ejournal.undiksha.ac.id/index.php/S1ak/article/download/9503/6069

Putri, R. A. (2015). Analisis Fraud Diamond dalam Mendeteksi Fraudulent Financial Statement (Studi Empiris pada Perusahaan Perbankan yang Terdaftar di Bursa Efek Indonesia Tahun 2011-2014). In Skripsi. Jurusan Akuntansi. Fakultas Ekonomi dan Bisnis. Universitas Islam Negeri Syarif Hidayatullah.

Ramamoorti, S. (2008). The Psychology and Sociology of Fraud : Integrating the Behavioral 
Sciences Component Into Fraud and Forensic Accounting Curricula. Issues in Accounting Education, 23(4), 521-533.

Ramamoorti, S. (2009). Bringing Freud to Fraud: Understanding the State-of-Mind of the C-Level Suite/White Collar Offender Through "A-B-C” Analysis. Journal of Forensic \& Investigative Accounting, 6(1), 1-35.

Ratmono, D., Diany, Y. A., \& Purwanto, A. (2018). Dapatkah Teori Fraud Triangle Menjelaskan Kecurangan Dalam Laporan Keuangan? Jurnal Akuntansi Dan Auditing, 14(2), 100. https://doi.org/10.14710/jaa.14.2.100-117

Reurink, A. (2018). Financial Fraud: a Literature Review. Journal of Economic Surveys, 32(5), 1292-1325. https://doi.org/10.1111/joes.12294

Said, J., Alam, M. M., Karim, Z. A., \& Johari, R. J. (2018). Integrating Religiosity Into Fraud Triangle Theory: Findings on Malaysian Police Officers. Journal of Criminological Research, Policy and Practice, 4(2), 111-123. https://doi.org/10.1108/JCRPP-09-20170027

Said, J., Alam, M. M., Ramli, M., \& Rafidi, M. (2017). Integrating Ethical Values Into Fraud Triangle Theory in Assessing Employee Fraud: Evidence from The Malaysian Banking Industry. Journal of International Studies, 10(2), 170-184. https://doi.org/10.14254/2071-8330.2017/10-2/13

Schuchter, A., \& Levi, M. (2016). The Fraud Triangle Revisited. Security Journal, 29(2), 107121. https://doi.org/10.1057/sj.2013.1

Sihombing, K. S., \& Rahardjo, S. nur. (2014). Analisis Fraud Diamond Dalam Mendeteksi Financial Statement Fraud: Studi Empiris Pada Perusahaan Manufaktur Yang Terdaftar Di Bursa Efek Indonesia (Bei) Tahun 2010 - 2012. Diponegoro Journal Of Accounting, 03(02), 1-12. https://doi.org/10.25105/semnas.v0i0.5780

Skousen, C. J., Smith, K. R., \& Wright, C. J. (2011). Detecting and Predicting Financial Statement Fraud: The Effectiveness of the Fraud Triangle and SAS No. 99. SSRN Electronic Journal, 99. https://doi.org/10.2139/ssrn.1295494

Smith, J. R., Tiras, S. L., \& Vichitlekarn, S. S. (2000). The Interaction between Internal Control Assessment and Substantive Testing in Audits for Fraud. Contemporary Accounting Research, 17(2), 327-356. https://doi.org/10.1506/P7V7-1VUY-0QP8$5 \mathrm{~W} 7 \mathrm{U}$

Sunardi, S., \& Amin, M. N. (2018). Fraud Detection of Financial Statement by Using Fraud Diamond Perspective. International Journal of Development and Sustainability, 7(3), 878891.

Suryani, I. C. (2019). Analisis Fraud Diamond Dalam Mendeteksi Financial Statement Fraud: Studi Empiris Pada Perusahaan Manufaktur Yang Terdaftar Di Bursa Efek Indonesia (Bei) Tahun 2016 - 2018. Prosiding Seminar Nasional Cendekiawan. https://doi.org/10.25105/semnas.v0i0.5780

Tempo.co. (2013). Polri Ungkap Kredit Fiktif di Bank Syariah Mandiri. Nasional.Tempo.Co. https:// nasional.tempo.co/read/524028/polri-ungkap-kredit-fiktif-di-bank-syariahmandiri

Tiffani, L., \& Marfuah. (2017). Deteksi Financial Statement Fraud Dengan Analisis Fraud Triangle Pada Perusahaan Aneka Industri Yang Terdaftar Di Bursa Efek Indonesia

JRAK 
Periode 2012- 2015”. Jurnal Akuntansi Dan Auditing Indonesia, 19(2), 112-125. https://doi.org/10.31629/jiafi.v1i1.1236

TrisnaDewi, C. (2018). Analisis Faktor yang Mmempengarubi Frand di Bank Syariah (Studi Empiris pada Bank Umum Syariah yang terdaftar di Bank Indonesia Periode 2012-2016).

Trompeter, G., Carpenter, T., Desai, N., Jones, K., \& Riley, R. (2013). A Synthesis of Fraud Related Research. Auditing: A Journal of Practice and Theory, 32, 287-321.

Wahyuninngtias, F. (2016). Analisis Elemen-elemen Fraud Diamond Sebagai Determinan Finansial Statement Fraud Pada Perusahaan Perbankan di Indonesia. In Tesis Universitas Airlangga. http://repository.unair.ac.id/55264/19/Tesis_Fauziah_W_1min.pdf

Wolfe, D. T., \& Hermanson, D. R. (2004). The Fraud Diamond: Considering the Four Elements of Fraud. The CPA Journal, 74(12), 38-42.

Yesiariani, M., \& Rahayu, I. (2016). Analisis Fraud Diamond dalam Mendeteksi Financial Statement Fraud (Studi Empiris pada Perusahaan LQ-45 yang Terdaftar di Bursa Efek Indonesia Tahun 2010 - 2014). Simposium Nasional Akuntansi XIX, Lampung, 1-22.

Zakaria, K. M., Nawawi, A., \& Salin, A. S. A. P. (2016). Internal Controls and FraudEmpirical Evidence from Oil \& Gas Company. Journal of Financial Crime, 23(4), 11541168. http://dx.doi.org/10.1108/eb025814\%5Cnhttp:// 